\title{
The Effect of Nutritional Status on Length of Hospital Stay in Adult Patients Undergoing Elective Orthopedic Surgery: A Prospective Analysis
}

\author{
Elektif Ortopedik Cerrahi Uygulanan Erişkin Hastalarda Beslenme Durumunun \\ Hastanede Yatış Süresine Etkisi: Prospektif Bir Analiz \\ ๑ Sibel Yılmaz Ferhatoğlu, @ Nezihe Ferah Dönmez* \\ University of Health Sciences Turkey, Dr. Siyami Ersek Thoracic and Cardiovascular Surgery Training and Research Hospital, Clinic of \\ Anesthesiology and Reanimation, Istanbul, Turkey \\ ${ }^{*}$ Koru Sincan Hospital, Clinic of Anesthesiology and Reanimation, Ankara, Turkey
}

Abstract

Aim: Malnutrition has been associated with morbidity and longer length of hospital stay. In this study, we aimed to investigate the effect of malnutrition on length of hospital stay in adult patients undergoing elective orthopedic surgery.

Methods: Three hundred and fifty of 1051 patients, who underwent orthopedic surgery between April 1, 2011 and May 30, 2011, were randomly enrolled in the study. The demographic data, nutritional and comorbidity status and post-operative data (complications, length of hospital stay) of the patients were prospectively recorded in the computer data system. The nutritional status of the patients was evaluated using the Nutritional Risk Screening-2002.

Results: A total of 314 patients were included in the study, $59.9 \%$ of whom were women. The mean age was $57.1 \pm 18.4$ years. Forty-nine point seven percent of the patients were younger than 65 years. The mean length of hospital stay was $6.14 \pm 4.69$ days. The risk of malnutrition in patients over 65 years of age was 7.47 times higher than in younger patients. The length of hospital stay was longer in patients with malnutrition risk $(p<0.01)$.

Conclusion: Our findings suggest that malnourished patients have an average of 1.36 days longer length of hospital stay and the resulting cost to the National/Social Health Service cannot be ignored.

Keywords: Malnutrition, NRS-2002, orthopedic surgery, nutrition
Amaç: Malnütrisyon, morbidite ve hastanede kalıs süresinin uzaması ile ilişkilidir. Bu çalışmada, elektif ortopedik cerrahi girişim yapılan erişkin hastalarda malnütrisyonun hastanede kalış süresi üzerine etkisini araştırmayı amaçladık.

Yöntemler: 01.04.2011 - 30.05.2011 tarihleri arasında ortopedi kliniklerinde yatan 1051 hastadan 350'si çalışmaya dahil edildi. Hastaların demografik verileri, beslenme ve komorbidite durumu ve operasyon sonrası verileri (komplikasyonlar, hastanede yatış süresi) bilgisayar veri sistemine prospektif olarak kaydedildi. Hastaların beslenme durumu, "Beslenme Risk Taraması (Nutritional Risk Screening-2002)" kullanılarak değerlendirildi.

Bulgular: Çalışmaya \%59,9’ u kadın olmak üzere toplam 314

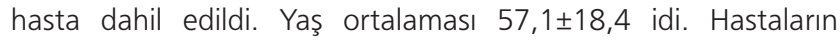
\%49,7 'si 65 yaşından küçük idi. Ortalama hastanede kalış süresi $6,14 \pm 4,69$ gün idi. Altmış beş yaş üstü hastalarda malnütrisyon riski 7,47 kat daha fazla bulundu. Malnütrisyon riski olan hastalarda yatış süresi daha uzun idi $(p<0,01)$.

Sonuç: Bulgularımız malnütrisyonlu hastaların ortalama 1,36 gün daha uzun hastanede yatış süresine sahip olduğunu göstermektedir ve ortaya çıkan maliyet göz ardı edilemez.

Anahtar Sözcükler: Malnütrisyon, NRS-2002, ortopedik cerrahi, beslenme
Address for Correspondence/Yazışma Adresi: Sibel Yılmaz Ferhatoğlu, University of Health Sciences Turkey, Dr. Siyami Ersek Thoracic and Cardiovascular Surgery Training and Research Hospital, Clinic of Anesthesiology and Reanimation, İstanbul, Turkey

E-mail: sibelyf@yandex.com ORCID: orcid.org/0000-0001-8726-0996

Received/Geliş Tarihi: 23 August 2019 Accepted/Kabul Tarihi: 04 February 2020
${ }^{\circ}$ Copyright 2020 by The Medical Bulletin of istanbul Haseki Training and Research Hospital The Medical Bulletin of Haseki published by Galenos Yayınevi. 'Telif Hakkı 2020 istanbul Haseki Eğitim ve Araştırma Hastanesi Haseki Tıp Bülteni, Galenos Yayınevi tarafından yayınlanmıștır 


\section{Introduction}

Malnutrition is a significant health problem, and its prevalence among patients treated in hospitals varies from $10 \%$ to $60 \%$ depending on the population, pathology, and test used (1-5). These rates rise due to lack of instructions to deal with nutritional problems, and lack of basic knowledge with respect to dietary requirements and practical aspects of the hospital's food provision $(6,7)$. Malnutrition has been associated with morbidity in both acute and chronic diseases (8). Malnourished patients have a longer hospital stay due to increased morbidity (9). It has been reported that the length of hospitalstay increased by $40-70 \%$ in patients with malnutrition compared to those without (8). Prolonged treatment periods and hospitalization periods create snowballing burdens on the National/Social Health Services of all countries.

A complete nutritional assessment can be made by considering subjective and objective parameters together (10). Over seventy techniques are used for identifying malnourished patients (11). In 2003, the European Society of Parenteral and Enteral Nutrition announced a guideline for the evaluation of the nutritional status of patients treated in hospitals and recommended the Nutritional Risk Screening-2002 (NRS-2002) developed to identify patients at risk of malnutrition in the hospital setting $(12,13)$. The number of scientific publications concerning malnutrition in hospitalized orthopedic patients has risen in the last decade. However, there are few studies using the NRS-2002 which is a reliable screening tool for the evaluation of malnutrition risk in patients undergoing elective orthopedic surgery (14-16). In the present study, we aimed to assess the prevalence of malnutrition in orthopedic patients as well as to investigate the association between malnutrition and selected clinical outcomes in these patients.

\section{Methods}

\section{Study Design}

The Ethics Committee of Ankara Numune Training and Research Hospital approved the study protocol (19.01.2011, 094/2011). Three hundred and fifty individuals, who underwent non-emergent orthopedic surgery performed by the same surgical team from April 2011 to May 2011 at the Ankara Numune Training and Research Hospital orthopedics and traumatology clinic, were enrolled in this prospective, observational cohort study. There were 30 resident doctors and 19 orthopedic surgeons who had at least five years of expertise.

A total of 350 of 1051 patients, who attended the outpatient clinic for preoperative examination for nonemergent orthopedic surgery, were randomly selected.
Patients under 18 years of age were not included in study. Individuals having malignant diseases $(n=3)$, communication disability (those using a different language, deaf, etc.) $(n=5)$, and individuals refusing to participate in the study $(n=28)$ were excluded.

The demographic data, nutritional and comorbidity status and post-operative data (complications, length of hospital stay) of the patients were prospectively recorded in the computer data system.

\section{Evaluation of Nutritional Status}

We used the NRS-2002 that recommended by ESPEN in hospitalized patients to evaluate the nutritional status of patients (13). The patients included in the study were divided into two groups according to malnutrition status. Patients with a NRS-2002 score of $\geq 3$ and $<3$ were included in risk group and non-risk group, respectively. The groups were compared according to age, gender, length of hospital stay, and comorbid conditions.

\section{Statistical Analysis}

According to power analysis, to obtain $80 \%$ power at a level of $0.05,350$ individuals were included in the study. The Number Cruncher Statistical System (NCSS) 2019 (Kaysville, Utah, USA) program was used for statistical evaluation. The Kolmogorov-Smirnov test was used to determine whether the data were parametric. According to parametric tests, frequency analyses were performed and interpreted as percentages. The Pearson chi-square was used to investigate the relationships between the groups. The relationship between the related variables was also measured with the Pearson correlation coefficient. Differences between the groups were investigated by a chi-square test, and the student's t-test was used to examine the differences. A p value of less than 0.05 was considered statistically significant.

\section{Results}

Three hundred and fourteen patients were included, $59.9 \%$ of whom were female. The mean age of the individuals was $57.1 \pm 18.4$ years. $49.7 \%(n=156)$ of the individuals were younger than 65 years. The mean length hospital stay was $6.14 \pm 4.69$ days. The mean age of the patients in the risk group was higher than in the nonrisk group ( $p=0.001)$. The risk of malnutrition was 7.47 times higher in patients aged $\geq 65$ [Odds ratio (OR): 7.475 (95\% Confidence interval (Cl): 4.18-13.37)] and in female patients $(p=0.001)$. The risk of malnutrition in females was 3.069 times higher than in males [OR: $3.069(95 \% \mathrm{Cl}$ : 1.78-5.29)] (Table 1).

The rate of malnourished patients was $29.3 \%$, and the risk of malnutrition was 2.86 times higher in patients with at least one comorbid condition $(p=0.001)$ [OR: 
2.866 (95\% Cl: 1.71-4.79)]. The risk of malnutrition was 2.58 times, 1.91 times and 4.34 times higher in patients with hypertension, Diabetes Mellitus and chronic arterial disease, respectively [OR: $2.582(95 \% \mathrm{Cl}: 1.57-4.23)]$, [OR: 1.914 (95\% Cl: 1.08-3.37)], [OR: 4.34 (95\% Cl: 1.969.61)], respectively) (Table 2,3).

Complications were found in $6.3 \%(n=20)$ of the patients, wound infection in $4.4 \%(n=14)$, pulmonary thromboembolism in $0.9 \%(n=3)$, atelectasis in $0.9 \%$ $(n=3)$ and pneumonia in $0.31 \%(n=1)$.

The length of hospital stay was significantly longer in risk group after the exclusion of complications $(p<0.01)$.

\begin{tabular}{|c|c|c|c|c|}
\hline & & \multicolumn{2}{|c|}{ Malnutrition risk } & \multirow[t]{3}{*}{$p$} \\
\hline & & \multirow{2}{*}{$\begin{array}{l}\begin{array}{l}\text { Risk+ } \\
(n=218)\end{array} \\
n(\%) \\
\end{array}$} & \multirow{2}{*}{$\begin{array}{l}\begin{array}{l}\text { Risk- } \\
(n=96)\end{array} \\
n(\%) \\
\end{array}$} & \\
\hline & & & & \\
\hline \multirow{4}{*}{$\begin{array}{l}\text { Age } \\
\text { (year) }\end{array}$} & $\begin{array}{l}\text { Min-max } \\
\text { (Median) }\end{array}$ & $18-89(54)$ & $18-93(72)$ & \multirow{4}{*}{$a_{0} 0.001$ ** } \\
\hline & Mean \pm SD & $51.73 \pm 17.23$ & $69.57 \pm 14.95$ & \\
\hline & $<65$ & $138(88.5)$ & $18(11.5)$ & \\
\hline & $\geq 65$ & $80(50.6)$ & $78(49.4)$ & \\
\hline \multirow[t]{2}{*}{ Gender } & Male & $104(82.5)$ & $22(17.5)$ & \multirow[t]{2}{*}{ b0.001** } \\
\hline & Female & $114(60.6)$ & $74(39.4)$ & \\
\hline \multicolumn{5}{|c|}{$\begin{array}{l}\text { SD: Standard deviation, min: Minimum, max: Maximum, n: Number } \\
\text { astudent t-test, bPearson chi-square test } \\
{ }^{*} p<0.05,{ }^{* *} p<0.01\end{array}$} \\
\hline
\end{tabular}

Table 2. Evaluation of chronic diseases according to malnutrition risk

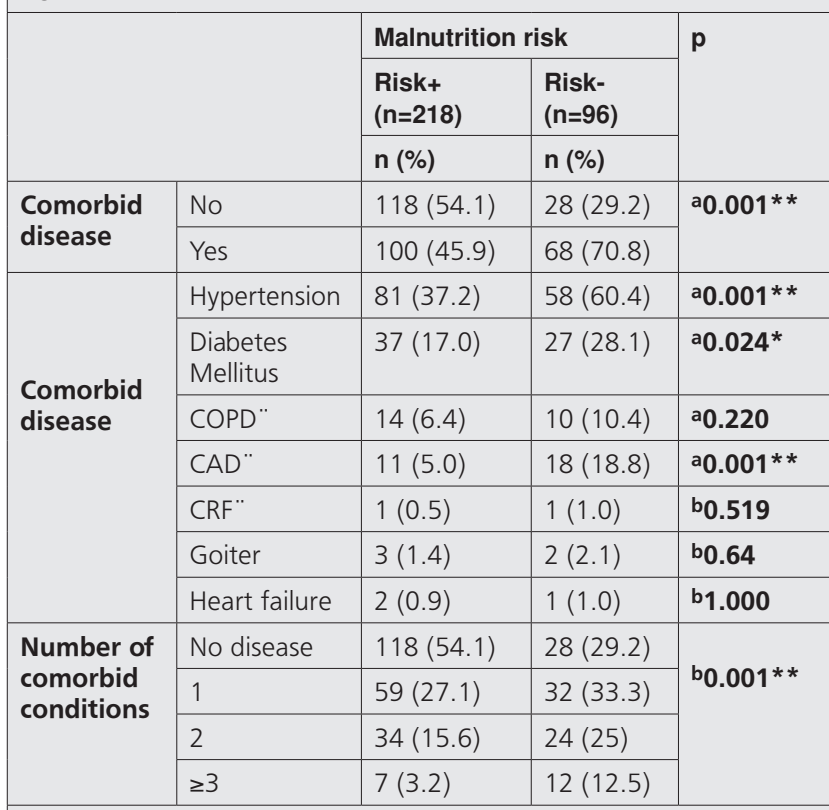

COPD: Chronic obstructive pulmonary disease, CAD: Chronic arterial disease, CRF: Chronic renal failure, $\mathrm{n}$ : Number

apearson chi-square test, bFisher's exact test ${ }^{* *} p<0.01,{ }^{*} p<0.05$
The mean postoperative hospital-stay in patients having normal nutritional status and malnourished patients was $5.45 \pm 3.49$ and $6.81 \pm 4.06$ days, respectively. The mean length of hospital stay in the risk group was 1.36 days longer than in non-risk group. Also, the risk of malnutrition was 1.55 times higher in patients with a length hospital stay of 5 days or more [OR:1.740 (95\% Cl:1.014-2.63)].

\section{Discussion}

The present study demonstrated three main findings: a-) the predominant age group for malnutrition risk was older than 65 years, b-) comorbidities increased the risk of malnutrition and indirectly prolonged the length of hospital stay, c-) length of postoperative hospital stay was longer in individuals having malnutrition risk after exclusion of complications $(p<0.01)$.

Decreased food intake is a significant determinant of chronic malnutrition amongst older adults, and this may be due to impaired sense of taste and smell, differences in hormones controlling gastric and intestinal motility, and alterations in mood associated with isolation, depression, and dementia (17). Nutritional evaluation is a cost-effective method to enhance nutrition state and assist in achieving more desirable functional recovery following an orthopedic operation $(18,19)$. Lumber et al. $(20)$ showed that patients having a high malnutrition risk at hospital admission were older than those in the low-risk group. The high predominance of malnutrition amongst older patients having orthopedic surgery, as well as the effects of malnutrition on length of hospital stay has been well shown (20-27).

Comorbid disease-related malnutrition is one of the most common comorbidities in all hospitalized patients (26), but it is usually a neglected diagnosis. This neglected pathologic condition increases the length of hospital stay, morbidity, and mortality. The association of comorbid disease and malnutrition is well recognized $(28,29)$. The finding of the present study shows that hypertension, Diabetes Mellitus, and coronary artery disease are comorbid conditions related to the risk of malnutrition in patients, candidate for non-emergent orthopedic surgery.

\begin{tabular}{l}
$\begin{array}{l}\text { Table 3. Logistic regression analysis results of factors affecting } \\
\text { malnutrition risk }\end{array}$ \\
\hline
\end{tabular}


Likewise, several researchers highlighted the influence of nutritional status on length of hospital stay (30-34). Kyle et al. (9) found a statistically significant relationship between malnutrition and length of hospital stay. Curtis et al. (35) revealed that the length of hospital stay in malnourished patients was approximately three days longer compared to well-nourished ones. In their cross-sectional study including 469 patients, Amaral et al. (36) reported that $42 \%$ of the patients were categorized as nutritionallyat-risk suggesting that disease-related malnutrition could represent an increment of 19.3\% in costs in Portuguese. The results of a study by Lim and Daniels (37) revealed that malnourished patients incurred higher hospitalization costs. In the present study, compatible with the literature, the length of hospital stay was longer in patients with malnutrition risk after the exclusion of complications $(p<0.01)$.

Malnutrition that exists in the patient may become more apparent during the hospital stay. Malnutrition should be considered an independent predictor of nosocomial infections and complications. Malnutrition is also associated with longer hospital stay and mortality $(9,30,38-40)$. Edington et al. (2) showed that malnourished patients had a longer hospital stay and had more postoperative infections. We found that the mean length of postoperative hospital stay was $5.45 \pm 3.49$ days in patients having normal nutritional status and $6.81 \pm 4.06$ days in malnourished patients after exclusion of complications.

Rasmussen et al. (41) reported that $40 \%$ of patients hospitalized in internal medicine, gastrointestinal surgery, and orthopedic surgery clinics were at nutritional risk, however, very few of them were identified. In the present study, we found that this rate was $29.3 \%$. Our outcomes are compatible with other research showing a high prevalence of malnutrition in hospitalized patients. The prevalence of malnutrition among hospitalized patients varies between $20 \%$ and $58.5 \%(1-5,41)$. Regarding the relevance of accurate description of malnutrition in this population, the use of a reliable screening tool should be guaranteed. In this project, we used the NRS-2002, whose predictive efficacy has been accurately proved to diagnose malnutrition and recommended by the European Society for Clinical Nutrition and Metabolism (42). Nevertheless, there is no consensus on which screening tool is better for detecting malnourished patients. Recently, Koren-Hakim et al. (24) demonstrated that the Mini Nutritional Assessment was a better tool as compared with the Malnutrition Universal Screening Tool and NRS-2002. However, Velasco et al. (43) argued that NRS-2002 was better than the Mini Nutritional Assessment and Malnutrition Universal Screening Tool. NRS-2002 includes the nutritional parts of the Malnutrition Universal Screening Tool, also, classification of the severity of the disease as a reflection of increased nutritional demands.

Besides, the Mini Nutritional Assessment Screening Tool is more likely to identify patients developing malnutrition risk, and malnutrition at an initial stage (24), since it also involves physical and mental aspects that frequently affect the nutritional status of the elderly, as well as a dietary questionnaire. It is, in fact, a combination of a screening and an assessment tool.

\section{Study Limitations}

Limitations of the present study involved a small sample size and short follow-up period due to single-center practice. Because of the absence of formally accepted, regular measures of nutritional state, comparison with other investigations are challenging. On the other hand, it should be considered that this research was carried in a single center. By incorporating more centers, these outcomes could be extended to different clinical perspectives. The results of this study could be doubted using evidence-based medicine by those who advocate the advantage of randomized clinical trials to support conclusions and define concepts. However, we believe that scientific development can be based on hypotheticodeductive processes, as occurred previously (44). As in the case of malnutrition, it would be unethical to randomize one group of individuals to starvation and compare their results to the group of fed individuals.

\section{Conclusion}

It is challenging to obtain an accurate assessment of the prevalence of malnutrition in patients admitted to hospital. Our findings suggest that malnourished patients have an average of 1.36 days longer hospital stay and the resulting cost to the National/Social Health Service cannot be ignored. There are two areas of further research which need to be addressed: health care experts can be enlightened to identify malnutrition and malnourished patients who need therapy. Just then, malnutrition would be appropriately managed. Furthermore, prospective randomized controlled studies are required to define whether improving nutritional state of malnourished patients is cost-effective.

\section{Authorship Contributions}

Concept: S.Y.F. Design: S.Y.F. Data Collection or Processing: S.Y.F. Analysis or Interpretation: S. Y.F. Literature Search: N.F.D. Writing: S.Y.F.

Conflict of Interest: No conflict of interest was declared by the authors.

Financial Disclosure: The authors declared that this study received no financial support. 


\section{References}

1. Bruun LI, Bosaeus I, Bergstad I, Nygaard K. Prevalence of malnutrition in surgical patients: evaluation of nutritional support and documentation. Clin Nutr 1999;18:141-7.

2. Edington J, Boorman J, Durrant ER, et al. Prevalence of malnutrition on admission to four hospitals in England. The malnutrition prevalence group. Clin Nutr 2000;19:191-5.

3. Waitzberg DL, Caiaffa WT, Correia MI. Hospital malnutrition: the Brazilian national survey (IBRANUTRI): a study of 4000 patients. Nutrition 2001:17;573-80.

4. Cereceda C, González I, Antolín FM, et al. Detection of malnutrition on admission to hospital. Nutr Hosp 2003;28:95-100.

5. van Bokhorst-de van der Schueren MA, Klinkenberg $M$, Thije A. Profile of the malnourished patient. Eur J Clin Nut 2004;59:1129-35.

6. Dupertuis YM, Kossovsky MP, Kyle UG, Raguso CA, Genton L, Pichard C. Food intake in 1707 hospitalized patients: a prospective comprehensive hospital survey. Clin Nutr 2003;22:115-23.

7. Kondrup J, Johansen N, Plum LM, et al. Incidence of nutritional risk and causes of inadequate nutritional care in hospitals. Clin Nutr 2002;21:461-8.

8. Norman K, Pichard C, Lochs H, Pirlich M. Prognostic impact of disease related malnutrition. Clin Nutr 2008;27:5-15.

9. Kyle UG, Pirlich M, Schuetz T, Lochs H, Pichard C. Is Nutritional Depletion by Nutritional Risk Index Associated with Increased Length of Hospital Stay? A Population-Based Study. J Parent Enteral Nutr 2004;28:999-104.

10. Shopbell JM, Hopkins B, Shronts EP. Nutrition screening and assessment; 2001.

11. Gottschich MM. (Ed) The Science and Practice of Nutrition Support. American Society for Parenteral and Enteral Nutrition (101-104) Dubuque: Kendal/Hunt Publishing.

12. Barendregt K, Soeters PB, Allison SP, Kondrup J. Basic concepts in nutrition. Diagnosis of malnutrition-screening assessment, The Europian e- journal of Clinical Nutrition and Metabolism 2008;3:121-5.

13. Kondrup J, Allison SP, Elia M, Vellas B, Plauth M. ESPEN Guidelines for Nutrition Screening 2002 Clinical Nutrition 2003;22:415-21.

14. Wilson JM, Holzgrefe RE, Staley CA, Schenker ML, Meals C. The Effect of Malnutrition on Postoperative Complications Following Surgery for Distal Radius Fractures. J Hand Surg Am 2019;44:742-50.

15. Chen Y, Wu X, Chen J, et al. Nutritional condition analysis of the older adult patients with femoral neck fracture. Clin Nutr. Clin Nutr 2019. pii: S0261-5614:30210-9. doi: 10.1016/j. clnu.2019.04.034. [Epub ahead of print]

16. Black CS, Goltz DE, Ryan SP, et al. The Role of Malnutrition in Ninety-Day Outcomes After Total Joint Arthroplasty. J Arthroplasty 2019;34:2594-600.
17. Elia M. Hunger disease Clin Nutr 2000;19:379-86.

18. Cabrerizo S, Cuadras D, Gomez-Busto F, Artaza-Artabe I, MarinCiancas F, Malafarina V. Serum albumin and health in older people: Review and meta-analysis. Maturitas 2015;81:17.

19. Malafarina $V$, Reginster JY, Cabrerizo S, et al. Nutritional Status and Nutritional Treatment Are Related to Outcomes and Mortality in Older Adults with Hip Fracture. Nutrients 2018;10:55.

20. Lumber M, Driver LT, Howland J, Older MJW, Williams CM. Nutritional status and clinical outcome in elderly female surgical orthopedic patients. Clin Nutr 1996;15:101-7.

21. Bell JJ, Bauer J, Capra S, Pulle CR. Barriers to nutritional intake in patients with acute hip fracture: time to treat malnutrition as a disease and food as a medicine? Can J Physiol Pharmacol 2013;91:489-95.

22. Paillaud E, Bories PN, Le Parco JC, Campillo B. Nutritional status and energy expenditure in elderly patients with recent hip fracture during a 2-month follow-up. Br J Nutr 2000;83:97-103.

23. Hanger HC, Smart EJ, Merrilees MJ, Frampton CM. The prevalence of malnutrition in elderly hip fracture patients. NZ Med J 1999;112:88-90.

24. Koren-Hakim T, Weiss A, Hershkovitz A, et al. Comparing the adequacy of the MNA-SF, NRS-2002 and MUST nutritional tools in assessing malnutrition in hip fracture operated elderly patients. Clin Nutr 2016;35:1053-8.

25. Li HJ, Cheng HS, Liang J, Wu CC, Shyu YI. Functional recovery of older people with hip fracture: does malnutrition make a difference? J Adv Nurs 2013;69:1691-703.

26. Drevet S, Bioteau C, Maziere S, et al. Prevalence of proteinenergy malnutrition in hospital patients over 75 years of age admitted for hip fracture. Orthop Traumatol Surg Res 2014;100:669-74.

27. Contel JC, Ledesma A, Blay C, et al. Chronic and integrated care in Catalonia [Internet] Int J Integr Care 2015;29:15-25.

28. Sanz París A, García JM, Go mez-Candela C, et al. Malnutrition prevalence in hospitalized elderly diabetic patients [Internet]. Nutr Hosp 2013;28:592-9.

29. Burgos R, Joaquin C, Blay C, Vaque C. Disease-related malnutrition in hospitalized chronic patients with complex needs. Clin Nutr 2019 [Ahead of print]

30. Díaz de Bustamante M, Alarco n T, Mene ndez-Colino R, Ramírez-Martín R, Otero A, Gnz alez-Montalvo Jl. Prevalence of malnutrition in a cohort of 509 patients with acute hip fracture: the importance of a comprehensive assessmentent. Eur J Clin Nutr 2018;72:77-81.

31. Correia I, Waitzberg DL. The impact of malnutrition on morbidity, mortality, length of hospital stay and costs evaluatthroughugh a multivariate model analysis. Clin Nutr 2003;22:235-9.

32. Naber HJ, Schermer T, De Bree A, Nusteling K, Eggink L, Kruimel WJ. Prevalence of malnutrition in nonsurgical hospitalized 
patients and associationism with disease complications. Am J Clin Nutr 1997;66:1232-9.

33. Goiburu ME, Goiburu MMJ, Bianco $H$, et al. The impact of malnutrition on morbidity, mortality and length of hospital stay in trauma patients. Nutr Hosp 2006;21:604-10.

34. Correia MI, Perman MI, Waitzberg DL. Hospital malnutrition in Latin America: A systematic review. Clin Nutr 2017;36:95867.

35. Curtis LJ, Bernier P, Jeejeebhoy K, et al. Costs of hospital malnutrition. Clin Nutr 2017;36:1391-6.

36. Amaral TF, Matos LC, Tavares MM, et al. The economic impact of disease-related malnutrition at hospital admission. Clin Nutr 2007;26:778-84.

37. Lim SL, Daniels L. Reply - Malnutrition and its impact on cost of hospitalization, length of stay, readmission and 3-year mortality. Clin Nutr 2013;32:489-90.

38. Martineau J, Bauer JInsertinging E, Cohen S. Malnutrition determined by the patient-generated subjective global assessment is associated with poor outcomes in acute stroke patients. Clin Nutr 2005;24:1073-7.
39. Allison SP. Malnutrition, disease and outcome. Nutrition 2000;16:590-3.

40. Marty CN, Winter PD, Coles SJ, Edington J. Effect of nutritional status the on use of health care resources by patients with chronic disease living in the community. Clin Nutr 1998; 17:119-23.

41. Rasmussen HH, Kondrup J, Staun M, Ladefoged K, Kristensen $\mathrm{H}$, Wengler $\mathrm{A}$. Prevalence of patients at nutritional risk in Danish hospitals. Clin Nutr 2004;23:1009-15.

42. Valero MA, Díez $L$, El Kadaoui $N$, Jiménez $A E$, Rodríguez $H$, León $\mathrm{M}$. Are the tools recommended by ASPEN and ESPEN comparable for assessing the nutritional status? Nutr Hosp 2005;20:259-67.

43. Velasco C, Garcia E, Rodriguez V, et al. Comparison of four nutritional screening tools to detect nutritional risk in hospitalized patients: a multicentre study. Eur J Clin Nutr 2011;65: 269-74.

44. Heymsfie SBS, Bethel RA, Asley JD, Gib DMD Fellnerner JM, Nutter DO. Cardiac abnormalities in cachectic patients before and during repletion. AM Heart J 1978;95:584-94. 